\title{
Kejadian Ekspulsi Alat Kontrasepsi Dalam Rahim Banded T-Shaped dan Plain T-Shaped pada Pemasangan Intra Seksio Sesarea
}

\author{
Dewi Novita, ${ }^{1}$ Umar Malinta, ${ }^{1}$ Samrichard Rambulangi, ${ }^{1}$ Firdaus Kasim ${ }^{2}$ \\ ${ }^{1}$ Departemen Obstetri dan Ginekologi Fakultas Kedokteran/Universitas Hasanuddin \\ ${ }^{2}$ Departemen IKM-IKK Fakultas Kedokteran/Universitas Hasanuddin \\ Korespondensi: Dewi Novita, Email: vitasyah911@gmail.com
}

\begin{abstract}
Abstrak
Tujuan: Mengetahui kejadian ekspulsi alat kontrasepsi dalam rahim banded T-shaped dan plain T-shaped pada pemasangan intra seksio sesarea.

Metode: Sebuah studi cohort dilakukan di 4 rumah sakit bersalin Makassar dari bulan September-Desember 2021. Sampel dibagi ke dalam dua kelompok yaitu mendapatkan banded T-shaped dan plain T-shaped.

Hasil: Ada 216 pasien yang dipasangkan AKDR. Tidak terdapat perbedaan proporsi penggunaan jenis AKDR $(\mathrm{p}>0.05)$. Perubahan letak AKDR terjadi pada hari ke-40 $(p(0.006)<0.05)$, pada hari ke-90 hari tidak terdapat perbedaan bermakna $(p(0.073>0.05)$. Pada hari ke-40 AKDR Banded T-shaped mengalami ekspulsi sebesar $20.4 \%$ sedangkan Plain T-shaped sebesar 8.3\% $(p(0.020)<0.05)$. Pada hari ke-90 kejadian AKDR Banded T-shaped sebesar 4.7\% sedangkan Palin T-shaped sebesar 5.1\% ( $p(1.000)>0.05)$.

Diskusi: Ekspulsi paling sering terjadi pada 30-90 hari setelah pemasangan akibat perubahan anatomi dan fisiologis selama masa nifas. Ekspulsi yang lebih rendah pada Plain T-shaped karena lengan horizontal yang fleksibel, teknik dengan pelebaran serviks yang lebih sedikit serta perdarahan lebih sedikit.

Kesimpulan: Kejadian ekspulsi tersering pada hari ke-40 dan menurun pada hari ke-90 pasca pemasangan. Jenis AKDR dengan kejadian ekspulsi paling sedikit adalah Plain T-shaped dibandingkan dengan Banded T-shaped.

Kata kunci: AKDR, Banded T-Shaped, Plain T-Shaped, Ekspulsi AKDR

\section{Incidence of Expulsion of Banded T-shaped and Plain T-shaped Intrauterine Device in Intra-Caecarean Delivery Insertion}

\begin{abstract}
Objective: Determine contraceptive device expulsion rate of banded T-shaped and plain T-shaped intra-cesarean. Method: A cohort study was conducted in 4 maternity hospitals at Makassar from September-December 2021. Samples were divided into two groups, getting Banded T-shaped and Plain T-shaped.

Result: There were 216 patients who had an IUD inserted. There was no difference in the proportion of the use of IUD types $(p>0.05)$. Changes in IUD position occurred on day $40(p(0.006)<0.05)$, on day 90 there was no significant difference ( $p(0.07>0.05)$. On day 40 the Banded T-shaped IUD expulsion was $20.4 \%$ while the Plain T-shaped was $8.3 \%(p(0.020)<0.05)$. On the 90th day the incidence of the Banded T-shaped IUD was 4.7\%, while the Plain T-shaped was $5.1 \%$ (p (1,000)>0.05).

Dicussion: Expulsion most often occurs 30-90 days after insertion due to anatomic and physiological changes during puerperium. Lower expulsion in plain T-shaped due to flexible horizontal arm, less cervical dilation technique and less bleeding.

Conclusion: The incidence of expulsion was most common on the 40th day and decreased on the 90th day after insertion. The type of IUD with the least number of expulsions was Plain T-shaped.
\end{abstract}

Key word : IUD, Banded T-Shaped, Plain T-Shaped, Expulsions IUD 


\section{Pendahuluan}

Berdasarkan data World Health Organization (WHO) tahun 2019 diantara 1,9 miliar wanita usia subuh (15-49 tahun), 1,1 miliar diantaranya memiliki kebutuhan menggunakan kontrasepsi, namun saat ini 842 juta menggunakan metode kontrasepsi modern dan 80 juta menggunakan metode tradisional. Sedang 190 juta wanita lainnya memilih untuk tidak menggunakan alat kontrasepsi. Untuk kontasepsi jangka panjang, salah satu yang disarankan adalah Alat Kontrasepsi Dalam Rahim (AKDR). ${ }^{1}$ Di Indonesia data statistik menunjukkan 7,75 dari 100 perempuan menggunakan kontrasepsi berupa AKDR. ${ }^{2}$

The U.S. Medical Eligibility Criteria for Contraceptive Use dan American College of Obstetricians and Gynecologists merekomendasikan pemasangan AKDR segera pasca melahirkan, karena tingkat komplikasi yang rendah seperti kejadian perforasi dan infeksi. ${ }^{3}$ Jenis AKDR yaitu mengandung hormon levonorgestrel (LNG) dan mengandung tembaga (TCu380A atau Paragard).

Angka kegagalan dari AKDR $<1 \%$ dan hampir sama dengan kontrasepsi mantap (sterilisasi). ${ }^{4}$ Penggunaan AKDR TCu380A Banded T-shaped merupakan yang paling efektif dan memiliki durasi kerja paling lama. ${ }^{28}$ AKDR umumnya dipasang pasca plasenta yang dilakukan dalam 10 menit pertama hingga 48 jam setelah plasenta lahir (atau sebelum penjahitan uterus/rahim pada pasca persalinan). AKDR merupakan metode kontrasepsi jangka panjang yang baik dan cocok digunakan pada semua wanita yang menjalani seksio sesarea, namun dengan efek samping terjadi peningkatan perdarahan masa nifas yang menyebabkan meningkatnya kejadian ekspulsi setelah pemasangan. ${ }^{4}$

Angka ekspulsi kumulatif selama 3 tahun mencapai $10 \%$. Angka ini lebih tinggi pada mereka yang berusia (+/-) 25 tahun. ${ }^{4}$
Kualitas, konfigurasi, kekakuan, ukuran dan bentuk dari AKDR merupakan faktor yang mempengaruhi kejadian ekspulsi. Selain itu, AKDR yang sesuai dengan konfigurasi kavum uterus memiliki angka insiden ekspulsi yang rendah. Tingkat ekspulsi AKDR meningkat jika digunakan segera pasca persalinan dibandingkan pada saat kunjungan postpartum. ${ }^{5}$

Angka ekspulsi AKDR dengan pemasangan pervaginam sebesar $14,8 \%$, sedangkan pemasangan intra seksio sesarea $3,8 \%$ (risk ratio, $4.57 \%$; 95\% confidence interval). ${ }^{10}$ Kejadian ekspulsi AKDR dari uterus sering terjadi selama bulan 1 pertama pemakaian, sehingga dianjurkan follow up posisi AKDR pada 1 bulan pertama, terutama setelah menstruasi. ${ }^{4}$

Berdasarkan uraian di atas, angka ekspulsi AKDR pada pemasangan intra seksio sesarea cukup tinggi. Hal tersebut disebabkan oleh beberapa hal seperti jenis AKDR yang digunakan berbeda-beda. Oleh karena itu penulis ingin melakukan penelitian mengenai kejadian ekspulsi AKDR Banded T-shaped dan Plain T-shaped pada pemasangan intra seksio sesarea, sehingga dapat dijadikan pertimbangan dalam penggunaan oleh tenaga kesehatan.

\section{Metode}

Penelitian ini merupakan penelitian kohort prospektif yang dilakukan di 4 rumah sakit bersalin di Makassar (RS Wahidin Sudirohusodo, RS Khadijah, RS Pertiwi, dan RS Fatimah). Pengamatan dilakukan selama 3 bulan yaitu selama periode September s/d Desember 2021.

Kriteria inklusi adalah semua ibu yang diindikasikan untuk operasi seksio sesarea dan bersedia untuk menjadi peserta penelitian, usia kehamilan cukup bulan ( $\geq 37$ minggu), dan kehamilan tunggal hidup.

Kriteria eksklusi adalah semua ibu dengan komplikasi hipotonia uteri atau 
atonia uteri intraoperatif, ditemukan kelainan anatomi selama operasi, riwayat kelainan anatomi uterus, riwayat perdarahan uterus abnormal yang tidak dapat dijelaskan penyebabnya, dan terdapat risiko infeksi. Pengambilan sampel dilakukan dengan cara consecutive sampling.

Prosedur pemasangan AKDR pasca plasenta intra seksio yaitu setelah melahirkan bayi dan plasenta, bersihkan kavum uterus dengan kasa steril dan betadin.

Operator kemudian menjepit AKDR di ujung jari tengah dan telunjuk yang selanjutnya menyusuri sampai ke fundus, meletakkan dan memastikan posisi AKDR pada tempatnya dan tidak dilakukan pemotongan benang AKDR.

Selanjutnya dilakukan penjahitan uterus dan jahit kulit secara subkutikuler dan kontrol perdarahan. Perubahan letak AKDR adalah berpindahnya letak AKDR sejauh 2,5 $\mathrm{mm}$ dari fundus uteri yang diukur dengan alat ultrasonografi.

Ekspulsi adalah keluarnya AKDR dari kavum uteri melalui kanalis servikalis, baik sempuna (complete expulsion, artinya seluruh AKDR telah keluar dari kavum uteri) maupun sebagian (partial expulsion, artinya sebagian AKDR terlihat keluar dari ostium uteri eksternum, tetapi sebagian yang lain masih tertahan di kavum uteri).

Data dianalisis dengan distribusi frekuensi dan persentase masing-masing variabel untuk menggambarkan karakteristik umur, lama menikah, profesi, pendidikan, paritas, riwayat aborsi, dan gangguan menstruasi.

Perbedaan tingkat ekspulsi AKDR antara 2 kelompok sampel digunakan uji $T$ Independen jika data berdistribusi normal, atau Mann-Whitney jika data tidak berdistribusi normal. Data dianalisis dengan SPSS 22.0 untuk Windows. Nilai $p$ kurang dari 0,05 dianggap signifikan secara statistik.
Hasil

Tabel 1 Karakteristik Subjek Penelitian

\begin{tabular}{|c|c|c|c|}
\hline \multicolumn{2}{|c|}{ Karakteristik } & \multirow{2}{*}{$\begin{array}{c}\mathbf{n} \\
7\end{array}$} & \multirow{2}{*}{$\begin{array}{c}\% \\
3.2\end{array}$} \\
\hline Usia & $<20$ tahun & & \\
\hline & 20-35 tahun & 174 & 80.6 \\
\hline & $>35$ tahun & 35 & 16.2 \\
\hline Lama & $<5$ tahun & 86 & 39.8 \\
\hline \multirow[t]{2}{*}{ Nikah } & 5-10 tahun & 97 & 44.9 \\
\hline & $>10$ tahun & 33 & 15.3 \\
\hline \multirow[t]{6}{*}{ Pekerjaan } & Guru & 1 & 0.5 \\
\hline & IRT & 209 & 96.8 \\
\hline & (ibu rumah tangga) & & \\
\hline & Swasta & 4 & 1.9 \\
\hline & PNS & 1 & 0.5 \\
\hline & Wiraswasta & 1 & 0.5 \\
\hline \multirow[t]{2}{*}{ Pendidikan } & SD-SMA & 196 & 90.7 \\
\hline & $\mathrm{D} 1-\mathrm{S} 2$ & 20 & 9.3 \\
\hline \multirow[t]{3}{*}{ Paritas } & Primipara & 47 & 21.8 \\
\hline & Multipara & 150 & 69.4 \\
\hline & Grande & 19 & 8.8 \\
\hline Riwayat & $\mathrm{Ya}$ & 30 & 13.9 \\
\hline Abortus & Tidak & 186 & 86.1 \\
\hline Gangguan & Dismenore & 35 & 16.2 \\
\hline \multirow[t]{3}{*}{ Haid } & Metroragia & 1 & 0.5 \\
\hline & Menometroragia & 1 & 0.5 \\
\hline & Lainnya & 179 & 82.9 \\
\hline
\end{tabular}

Tabel 2 Perbandingan Perubahan Letak AKDR antara Jenis Plain T-shaped dan Banded T-shaped pada Pengamatan hari 40 dan 90

\begin{tabular}{lcccc}
\hline \multirow{2}{*}{ AKDR } & \multicolumn{4}{c}{ 40 Hari dan 90 hari } \\
\cline { 2 - 5 } & mean & SD & mean & SD \\
\hline Plain T-shaped & 1.07 & 0.86 & 0.90 & 0.80 \\
\hline Banded T-shaped & 1.49 & 1.12 & 0.97 & 0.70 \\
\hline Nilai $p$ & $0.006^{*}$ & $0.073^{*}$ \\
\hline * Uji Mann Whitney \\
\hline
\end{tabular}

Ekspulsi AKDR di Kota Makasar selama bulan September-Desember 2021 sebanyak 40 kasus. Ekspulsi AKDR Plain T-shaped 
Tabel 3 Perbandingan Proporsi Yang Mengalami Ekspulsi pada Hari ke 40 dan 90

\begin{tabular}{|c|c|c|c|c|c|c|c|c|c|}
\hline \multirow[t]{3}{*}{ AKDR } & \multicolumn{9}{|c|}{ Ekspulsi } \\
\hline & \multicolumn{4}{|c|}{ Hari 40} & \multicolumn{4}{|c|}{ Hari 90} & \\
\hline & $\mathrm{Ya}$ & Tidak & Jumlah & Nilai $p$ & $\mathrm{Ya}$ & Tidak & Jumlah & Nilai $p$ & \\
\hline \multirow{2}{*}{$\begin{array}{l}\text { Plain T- } \\
\text { shaped }\end{array}$} & $\mathrm{n}$ & 9 & 99 & 108 & \multirow{6}{*}{$0.020^{*}$} & 5 & 94 & 99 & \multirow{6}{*}{$1.000^{*}$} \\
\hline & $\%$ & $8.3 \%$ & $91.7 \%$ & $100.0 \%$ & & $5.1 \%$ & $94.9 \%$ & $100.0 \%$ & \\
\hline \multirow{2}{*}{$\begin{array}{l}\text { Banded T- } \\
\text { shaped }\end{array}$} & $\mathrm{n}$ & 22 & 86 & 108 & & 4 & 82 & 86 & \\
\hline & $\%$ & $20.4 \%$ & $79.6 \%$ & $100.0 \%$ & & $4.7 \%$ & $95.3 \%$ & $100.0 \%$ & \\
\hline \multirow{2}{*}{ Jumlah } & $\mathrm{n}$ & 31 & 185 & 216 & & 9 & 176 & 185 & \\
\hline & $\%$ & $14.4 \%$ & $85.6 \%$ & $100.0 \%$ & & $4.9 \%$ & $95.1 \%$ & $100.0 \%$ & \\
\hline
\end{tabular}

* Uji Mann Whitney

sebanyak 14 kasus dan Banded T-shaped sebanyak 26 kasus.

Ciri-cirinya dapat dilihat pada Tabel 1. Pengguna AKDR paling sering pada usia 20-35 tahun (80,6\%), lama menikah 5-10 tahun $(44,9 \%)$, ibu rumah tangga $(96,8 \%)$, pendidikan SD-SMA ( 90,7), multiparitas $(69,4 \%)$, tanpa riwayat abortus $(86,1 \%)$, dan gangguan menstruasi berupa dismenore.

Pada penelitian ini ditemukan perubahan letak yang lebih rendah pada posisi AKDR Plain T-shaped pada hari ke-40 $(p=0,006)$ dan ekspulsi yang lebih rendah juga terjadi pada hari ke-40 $(p=0,020)$. Perubahan posisi dan ekspulsi pada hari ke-90 tidak berbeda secara signifikan.

\section{Pembahasan}

Pengguna kontrasepsi AKDR berada pada rentang usia dewasa muda. Sesuai dengan penelitian oleh Aldriana (2013) dan Getinet et al (2014) yang menyatakan penggunaan kontrasepsi termasuk AKDR terbanyak berada pada usia 20-35 tahun. $^{6}$ Usia mempengaruhi kemampuan seseorang untuk hamil, masa subur berlangsung pada usia 20-35 tahun, semakin tua usai makin rendah angka kehamilan, ekspulsi dan kegagalan AKDR. ${ }^{7}$

Pemilihan jenis AKDR didominasi oleh wanita dengan status IRT yang tidak bekerja. Sesuai dengan penelitian Triyanto dan Indirani (2018) yang menunjukkan tidak terdapat hubungan antara status pekerjaan ibu dengan pemilihan kontrasepsi AKDR. Status pekerjaan tidak sepenuhnya mempengaruhi penggunaan kontrasepsi di Indonesia. Kebanyakan ibu yang tidak bekerja juga akan memilih alat kontrasepsi jangka panjang, dengan pertimbangan bahwa tuntutan pekerjaan sebagai IRT mengharuskan ibu untuk tidak hamil. Ibu yang tidak bekerja lebih banyak memilih AKDR sebagai alat kontrasepsi dikarenakan lebih aman, praktis dan bisa bertahan dalam jangka lama. ${ }^{8}$ Namun penelitian Teferra dan Wondifraw (2015) menujukkan bahwa wanita bekerja cenderung menggunakan kontrasepsi dibandingkan mereka yang tidak bekerja. ${ }^{8}$ Kesempatan wanita bekerja untuk mengurus anak lebih sedikit, sehingga cenderung memakai alat kontrasepsi jangka panjang.

Pengguna AKDR terbanyak dengan pendidikan SD-SMA. Dari data yang ditemukan, tingkat pendidikan SD merupakan pengguna terbanyak alat kontrasepsi modern termasuk AKDR. Pendidikan berpengaruh besar terhadap cara pandang positif dan sikap terhadap keluarga berencana. Namun, apapun tingkat pendidikannya, akseptor KB yang telah memiliki pengetahuan yang baik tentang penggunaan kontrasepsi, mereka juga lebih cenderung mengunjungi klinik kesehatan dan tentunya lebih cenderung 
menggunakan alat kontrasepsi. Hasil tersebut sama dengan hasil penelitian Triyanto dan Indriani (2018) yang menyebutkan bahwa tingkat pendidikan tidak akan mempengaruhi pemilihan metode kontrasepsi AKDR. ${ }^{9}$ Namun penelitian yang dilakukan oleh Putri dkk (2013), menggambarkan bahwa pemakaian metode kontrasepsi dipengaruhi oleh tingkat pendidikan. ${ }^{10}$ Tingkat pendidikan ini mempempengaruhi keputusan dalam memilih metode kontrasepsi karena sangat berpengaruh terhadap persepsi, pola pikir serta perilaku untuk pengambilan keputusan tentang kesehatannya. Perempuan berpendidikan tinggi lebih mungkin menerima metode kontrasepsi modern karena kesempatan penerimaan informasi dari media massa lebih besar untuk menerima layanan informasi dari tenaga kesehatan.

Paritas merupakan salah satu indikator yang diperhatikan dalam pemilihan kontrasepsi. Menurut Pastuty (2005), semakin banyak jumlah anak yang pernah dilahirkan, semakin berpeluang besar untuk ibu memiliki keinginan membatasi kelahiran.

Kondisi ini akan mendorong akseptor untuk memakai kontrasepsi AKDR. ${ }^{11}$

Menurut penelitian Mutiarawati (2014) terdapat hubungan antara jumlah anak dengan pemilihan jenis kontrasepsi, terutama ibu yang sudah memiliki $\geq$ tiga anak. $^{12}$ Rendahnya pemilihan pemakaian AKDR pada paritas rendah karena merasa malu, risih, takut dengan teknik pemasangan, rendahnya dukungan suami karena merasa tidak nyaman saat berhubungan, kecemasan akan masuk menembus dinding rahim, risiko penyakit infeksi dan keputihan, dan menganggap menggunakan AKDR terlalu lama akan menyulitkan pada saat pencabutan. Hal disebabkan oleh minimnya pengetahuan akseptor KB mengenai metode pemasangan atau pemakaian alat kontrasepsi.

Penelitian oleh Dewan et al (2018) yang menyatakan tidak ada hubungan antara riwayat abortus dengan pemilihan jenis AKDR. ${ }^{13}$ Semua jenis AKDR tidak dipengaruhi riwayat abortus, dan pilihan efektif tentang penggunaan kontrasepsi dengan riwayat abortus adalah AKDR, tetapi tidak didapatkan data yang spesifik untuk pilihan jenis AKDR yang paling efektif. ${ }^{14}$ Studi Ferreira et al (2010) menemukan tingginya pemilihan metode kontrasepsi pasca aborsi menunjukkan adanya berbagai manfaat dari keluarga berencana khususnya setelah aborsi. Salah satunya adalah memberikan waktu untuk pemulihan kondisi rahim dan pemeriksaan untuk mengetahui penyebab aborsi untuk persiapan kehamilan berikutnya. ${ }^{15}$

Perubahan siklus menstruasi umumnya terjadi pada pasien yang menggunakan kontrasepsi AKDR. Perubahan siklus tersebut terjadi pada 90 hari pertama dan akan mengalami penurunan setelah 90 hari selanjutnya hal ini disebabkan oleh enzim-enzim yang merusak protein dan mengaktivasi plasminogen activators yang terkumpul dalam jaringan endometrium yang berhubungan dengan AKDR. ${ }^{7}$ Hampir semua AKDR yang mengandung tembaga mengalami peningkatan jumlah atau lama perdarahan menstruasi sedangkan AKDR hormonal akan mengurangi jumlah darah menstruasi. ${ }^{4}$ Insersi AKDR menyebabkan meningginya konsentrasi plasminogen activators dalam endometrium, dan enzim enzim ini yang menyebabkan meningkatnya aktivitas fibrinolitik. ${ }^{7}$ Adanya AKDR pada uterus dianggap meningkatan prostaglandin sehingga menyebabkan terjadinya kontraksi uterus yang menyababkan dismenorea.

Gangguan menstruasi sering terjadi pada pengguna jenis AKDR tembaga. Dismenorea pada pengguna AKDR terjadi dikarenakan iritasi dinding uterus oleh lengan transversal AKDR. ${ }^{4}$

Ekspulsi AKDR adalah terlepasnya AKDR dari uterus, paling sering terjadi pada 30-90 hari setelah pemasangan. ${ }^{4}$ Pada penelitian ini didapatkan Plain T-shaped 
menunjukkan proteksi yang baik dan expulsion rate sebesar $4,1 \%$ yaitu lebih rendah dibandingkan dengan Banded T-shaped sebesar 10,8\%. Sesuai dengan penelitian Haugan et al. (2007) yaitu Plain T-shaped memiliki expulsion rate sebesar $0,7 \%$ sedangkan Banded T-shaped sebesar 3,1\% per 100 wanita per tahun. Hasil penelitian ini menunjukan bahwa expulsion rate Plain T-shaped lebih rendah dibandingkan dengan Banded T-shaped. ${ }^{16}$

Pada penelitian Batar et al (2002), Plain T-shaped memberikan proteksi terhadap kehamilan yang tidak diinginkan dengan angka kejadian $0.5 \%$ dalam 1 tahun dan $1.9 \%$ dalam 5 tahun dibandingkan dengan jenis AKDR lainnya yang memiliki luas permukaan tembaga yang lebih besar. ${ }^{17}$ Namun, tidak sesuai dengan penelitian oleh Ragab et al (2015) yang menemukan ekpulsi AKDR jenis Banded T-shaped lebih rendah daripada Plain T-shaped. ${ }^{18}$ Penelitian Thonneau dan Almont (2008) juga menemukan jenis AKDR yang paling efektif Banded T-shaped dibanding jenis lainya. ${ }^{19}$

Ekspulsi yang lebih rendah pada Plain T-shaped dikaitkan dengan memiliki lengan horizontal yang fleksibel (yang memungkinkan adaptasi ke dalam rahim), teknik pemasangan yang unik yang membutuhkan lebar serviks yang lebih sedikit serta perdarahan lebih sedikit. Hal tersebut menyebabkan perubahan letak hingga tingkat perubahan ekspulsi yang rendah. ${ }^{16}$ Selain itu perubahan letak lebih rendah pada AKDR yang memiliki kandungan tembaga lebih rendah. ${ }^{20}$ Menurut Dennis dan Hampton (2002) ditemukan Plain T-shaped memiliki kandungan tembaga $200 \mathrm{~mm}^{2}$ dibandingkan Banded T-shaped yang memiliki kandungan tembaga $280 \mathrm{~mm}^{2}$. Tingginya angka kejadian perdarahan pada pengguna AKDR Banded T-shaped yang merupakan alasan utama dalam ekspulsi AKDR. ${ }^{20}$

Faktor yang menyebabkan ekspulsi juga antara lain termasuk derajat serviks dilatasi pada saat insersi - dengan peningkatan risiko jika serviks dilatasi $2 \mathrm{~cm}$ atau lebihdan jarak antara fundus uterus dan AKDR selama insersi - dengan risiko menurun saat AKDR lebih dekat ke fundus. Faktorfaktor ini dapat menjelaskan tingkat ekspulsi yang lebih rendah setelah insersi AKDR intra seksio sesarea dibandingkan persalinan pervaginam, karena faktor terakhir dilakukan dengan insersi buta menggunakan forsep Kelly. AKDR juga dapat bergerak secara vertikal dalam rongga rahim dikaitkan dengan perubahan ketebalan endometrium selama siklus menstruasi. ${ }^{21}$ Selain itu perubahan letak hingga ekspulsi pada pemasangan AKDR post plasenta tetap bervariasi di seluruh penelitian, tetapi pemasangan pasca persalinan antara 10 menit dan 48 jam pasca persalinan dikaitkan dengan peningkatan risiko perubahan letak dan ekspulsi jika dibandingkan dengan pemasangan interval pada 4-6 minggu pasca persalinan. ${ }^{4}$

Ekspulsi lebih sering terjadi pada tiga bulan pertama setelah pemasangan, setelah itu angka kejadian menurun tajam. Hal tersebut akibat perubahan anatomi dan fisiologis selama masa nifas yang dapat meningkatkan risiko ekspulsi. Subinvolusi uterus, kontraksi berlebihan, dan dilatasi serviks yang terus-menerus akibat lewatnya lokia yang berlebihan juga dapat meningkatkan risiko ekspulsi. Terbukti sebagian besar ekspulsi dan perpindahan terjadi selama 90 hari pertama setelah melahirkan. Semua faktor ini memvalidasi tingkat ekspulsi yang lebih tinggi yang diamati setelah insersi pascapartum segera daripada insersi interval. ${ }^{19}$ Selain itu penyebab ekspulsi karena ukuran AKDR terlalu kecil atau terlalu besar (AKDR yang terlalu kecil lebih tinggi angka ekspulsi dari pada AKDR yang lebih besar) dan karena letak AKDR yang tidak sempurna di dalam uterus. $^{4}$

Hal ini sesuai dengan penelitian Faundes et al. (2000) yag mengamati perubahan posisi AKDR hari ke-1, 30, dan 90. Tujuh belas 
malposi selama 90 hari pertama. Namun, pada 90 hari pasca pemasangan hanya enam yang mengalami malposisi. Penulis menyimpulkan bahwa AKDR tidak mengakomodasi posisinya di dalam rongga rahim dan dapat bergerak ke atas dan ke bawah. ${ }^{22}$

Demikian pula, Morales-Rosello et al (2005) menemukan bahwa 97\% dari 32 orang pengguna AKDR mengalami perubahan lekat selama 2 bulan setelah pemasangan. Mereka juga menyimpulkan bahwa ada pergerakan AKDR di dalam rahim dalam beberapa bulan pertama setelah pemasangan. ${ }^{23}$

Penelitian Lara et al (2006) yang melibatkan 157 wanita, juga menunjukkan tingkat ekspulsi masing-masing adalah 9\% dan 13\% setelah pemasangan intra seksio sesarea dan persalinan pervaginam. ${ }^{24}$

Multipara memiliki proporsi tertinggi untuk mengalami kejadian ekspulsi AKDR. Sesuai dengan penelitian Garishah (2013) bahwa terdapat hubungan signifikan antara paritas dengan kejadian ekspulsi AKDR, dengan persentase kejadian ekspulsi multipara lebih besar dibandingkan dengan primipara. Multipara merupakan faktor resiko tinggi untuk terjadinya ekspulsi AKDR pasca plasenta yang mencapai $95 \%$ dalam jangka waktu satu tahun setelah pemasangan. Paritas tinggi memiliki kecenderungan ekspulsi yang lebih tinggi disebabkan oleh dilatasi serviks yang lebih luas dan luas serta elastisitas endometrium yang lebih tinggi. ${ }^{7,25}$

Namun kejadian ekspulsi AKDR tidak hanya tergantung dari faktor paritas akseptor tetapi faktor waktu pemasangan itu sendiri dan faktor lain seperti konfigurasi kavum uterus, aktifitas seksual, ukuran, kontraksi endometrium, aktifitas sehari-hari yang tidak diteliti penelitian ini, sehingga menjadi keterbatasan pada peneltian ini.

Sebagai kesimpulan, penelitian ini menunjukkan angka kejadian ekspulsi AKDR pada pemasangan intra seksio sesarea tersering pada hari ke-40 dan menurun pada hari ke-90 pasca pemasangan. Adapun faktor yang mempengaruhi antara lain subinvolusi uterus, kontraksi berlebihan, dan dilatasi serviks yang terus-menerus. Sedangkan jenis AKDR dengan kejadian ekspulsi paling rendah adalah Plain T-shaped dibandingkan dengan Banded T-shaped. Adapun faktor yang mempengaruhi antara lain Plain T-shaped memiliki lengan horizontal yang fleksibel, teknik pemasangan yang membutuhkan lebar serviks lebih sedikit, perdarahan lebih sedikit, dan memiliki kandungan tembaga lebih rendah.

\section{Conflict of Interest}

Penelitian ini tidak disponsori atau dibiayai oleh pihak manapun.

\section{Saran}

Perlu penelitan lanjutan dengan jangka waktu penelitian yang lebih lama dan juga menambahkan faktor-faktor determinan lain yang berpengaruh terhadap hasil penelitian yaitu ukuran uterus dan faktor predisposisi lainnya.

\section{Daftar Pustaka}

1. World Health Organization. Contraceptive use by method 2019. United Nations, Department of Economic and Social Affairs. 2019. Available from: https://www.un.org/en/development/ desa/population/publications/pdf/family/ eptiveUseByMethodDataBooklet2019

2. BBKBN. Pedoman Pelayanan Keluarga Berencana Pasca Persalinan di Fasilitas Kesehatan. 2015.

3. American College of Obstetricians and Gynecologists. Obstet Gynecol. Immediate postpartum long-acting reversible contraception. Committee Opinion. 2016; 670:128:e32-7. [PubMed: 27454734]

4. Cunningham, et al. Williams Obstetrics. 
25th ed. McGraw Hill. 2018.

5. Lester F, Kakaire O, Byamugisha J, Averbach S, Fortin J, Maurer R, et al. Intracesarean insertion of the Copper BANDED T-SHAPED versus 6 weeks postcesarean: a randomized clinical trial. Contraception. 2015; 91:198-203. [PubMed: 25499587]

6. Getinet, S., Abdrahman, M.A., Kemaw, N., Kansa, T., Getachew, Z., Hailu, D., Workineh, Y. Long Acting Contraceptive Method Utilization and Associated Factors among Reproductive Age Women in Arba Minch Town, Ethiopia. Greener Journal of Epidemiology and Public Health. 2014; 2(1): 23-31

7. Hartanto, H. Keluarga Berencana dan Kontrasepsi. Jakarta: Pustaka Sinar Harapan. 2010.

8. Teferra, A.S., Wondifraw, A.A. Determinants of Long Acting Contraceptive Use among Reproductive Age Women in Ethiopia: Evidence from EDHS 2011. Science Journal of Public Health. 2015; 3(1): 143-149.

9. Triyanto Luki dan Indriani Diah. Faktor yang Mempengaruhi Penggunaan Jenis Metode Kontrasepsi Jangka Panjang (MKJP) pada Wanita Menikah Usia Subur di Provinsi Jawa Timur. The Indonesian Journal of Public Health. 2018; 13(2).

10. Putri Rani Pratama, Sari Ratna Dewi Puspita, Ayu Putu Ristyaning. Perbandingan Faktor-Faktor yang Mempengaruhi Penggunaan Kontrasepsi Intra Uterine Devices (IUD) dan Kontrasepsi Implant pada Wanita Usia Subur di Kecamatan Sukarame Kota Bandarlampung. Majority. 2019; 8(2): 120124.

11. Pastuty R. Hubungan Demand KB dengan Penggunaan Kontrasepsi [Tesis]. Yogyakarta: Pascasarjana Universitas Gajah Mada. 2005

12. Muatiarawati AMIM. Faktor-Faktor Yang Berhubungan Dengan Pemilihan
Alat Kontrasepsi Pada Akseptor KB Wanita Di Tuwel.Jurnal Kesehatan. 2014; 2(2):1-10.

13. Dewan, R., et al. Early IUD insertion after medically induced abortion, Eur J Contracept Reprod Health Care. 2018; 23(3): 231-236. doi: 10.1080/13625187.2018.1473569.

14. Cremer M, Bullard KA, Mosley RM, et al. Immediate vs. delayed post-abortal copper T 380A IUD insertion in cases over 12 weeks of gestation. Contraception. 2011; 83(6):522-527. doi:10.1016/j. contraception.2010.10.005

15. Ferreira Ana Laura CG, Souza Ariani I, Lima Raitza A and Braga Cynthia. Choices on contraceptive methods in post-abortion family planning clinic in the northeast Brazil. Reproductive Health. 2010: 7:5. http://www.reproductivehealth-journal.com/content/7/1/5

16. Haugan, T., Skjeldestad, F. E., Halvorsen, L. E., \& Kahn, H. A randomized trial on the clinical performance of Nova $\mathrm{T} \circledast 380$ and Gyne T®380 Slimline copper IUDs. Contraception. 2007; 75(3): 171-176. doi:10.1016/j.contraception.2006.09.005

17. Batár, I., Kuukankorpi, A., Siljander, M., Elomaa, K., \& Rauramo, I. Five-year clinical experiences with NOVA T®380 copper IUD. Contraception. 2002; 66(5): $\quad 309-314$. doi:10.1016/s00107824(02)00385-2

18. Ragab, A. et al. Expulsion of Nova-T380 , Multiload 375, and Copper-T380A contraceptive devices inserted during cesarean delivery. International Journal of Gynecology and Obstetrics. 2015; 130: 174-178. doi: 10.1016/j. ijgo.2015.03.025.

19. Thonneau P, Almont T. Contraceptive efficacy of intrauterine device, American journal of Obstetrics and Gynecology. 2008; 198 (3): 248-253.

20. Dennis, J. and Hampton, N. IUDs: Which device? Journal of Family Planning and 
Reproductive Health Care. 2002; 28(2): 61-68.

21. Faundes D, Bahamondes L, Faundes A, et al. T-shaped IUDmove vertically with endometrial growth and involution duringthe menstrual cycle.Contraception. 1998; 57: 413-415.

22. Faundes D, Perdigao A, Faundes A,et al. T-shaped IUDs accommodate in their position during the first 3 months afterinsertion. Contraception. 2000; 62: 165-168.

23. Morales-Rosello J. Spontaneous upward movement of lowlyplaced T-shaped IUDs.Contraception. 2005; 72: 430-431.

24. Lara Ricalde R, Menocal Tobías G, Ramos Pérez C, Velázquez Ramírez N. 2006. Random comparative study between intrauterine device Multiload $\mathrm{Cu} 375$ and $\mathrm{TCu} 380 \mathrm{a}$ inserted in the postpartum period (in Spanish). Ginecol Obstet Mex. Vol 74(6): 306-11.

25. Garishah, Ginesha H. Hubungan Antara Paritas Terhadap Kejadian Ekspulsi IUD pada Akseptor IUD Post Plasental Delivery pada Persalinan Spontan di Kota Magelang [Skripsi]. Yogyakarta: Pendidikan Dokter Fakultas Kedokteran dan Ilmu Kesehatan Universitas Muhamadiyah Yogyakarta. 2013. 